\title{
Producers profile and the adoption of technologies in passion fruit cultivation in the Triângulo Mineiro region
}

\author{
Aline Oliveira Zacharias ${ }^{1}$, Fábio Gelape Faleiro ${ }^{2}$, Gabriella Queiroz de Almeida ${ }^{3}$
}

\begin{abstract}
Productivity of passion fruit in Brazil varies widely among producers in different states and regions depending on the adoption of technologies. In this study, the goal was to evaluate the producers profile and use of technologies in passion fruit production in the Triângulo Mineiro region, driven by the local juice industry. The research was carried out from 2018 to 2019, using Behavioral Diagnosis of Productive Activity methodology, based on questionnaires applied to 22 producers in eight cities. The data were submitted to descriptive and multivariate statistical analysis. Most producers grow passion fruit in up to 5 ha, in a family work regimen, and have little experience. The cultivation system is open field in vertical trellis, with a production cycle of 1.5 years. The great majority use manual pollination, chemical and organic fertilization, and do not systematically adopt integrated phytosanitary management. The seedlings are purchased from qualified nurseries and the most planted cultivar is the FB 300 . The main losses reported by producers were caused by drought and damage to floral bud, with an average fruit yield of $17 \mathrm{tha}^{-1}$ year $^{-1}$. This production chain is structured but requires technical interventions to increase the profitability and sustainability of the production system.
\end{abstract}

Index terms: Passiflora, productive system, technology, Minas Gerais

\section{Perfil dos produtores e da adoção de tecnologias no cultivo de maracujá na região do Triângulo Mineiro}

Corresponding author: aline.zacharias@embrapa.br

Received: May 09, 2020 Accepted: July 28, 2020

Copyright: All the contents of this journal, except where otherwise noted, is licensed under a Creative Commons Attribution License.
Resumo - A produtividade do maracujazeiro no Brasil possui grandes variações entre produtores de diferentes Estados e regiões, em função de tecnologias adotadas. Neste trabalho, objetivou-se avaliar o perfil dos produtores e o uso de tecnologias na atividade produtiva de maracujá, na região do Triângulo Mineiro, impulsionada pela indústria de suco local. A pesquisa foi feita de 2018 a 2019, utilizando a metodologia do Diagnóstico Comportamental da Atividade Produtiva (DCAP), a partir da análise do perfil de 22 produtores, em oito municípios, e os dados foram submetidos à análise estatística descritiva e multivariada. A maioria dos produtores cultiva maracujá em até 5 ha, em regime familiar de trabalho, e possui pouco tempo de experiência. O sistema de cultivo é a céu aberto em espaldeira, com ciclo de produção de 1,5 ano. A maioria dos produtores faz polinização manual, adubação química e orgânica, e não adota, sistematicamente, o manejo integrado de pragas e doenças. As mudas são adquiridas de viveiros habilitados, e a cultivar mais plantada é a FB 300. Os principais prejuízos relatados foram causados por seca e danos no botão floral, com produtividade média de frutos de $17 \mathrm{t} \mathrm{ha}^{-1} \mathrm{ano}^{-1}$. A cadeia produtiva está estruturada, mas há necessidade de intervenções técnicas para aumentar a rentabilidade e a sustentabilidade do sistema de produção.

Termos para indexação: Passiflora, sistema produtivo, tecnologia, Minas Gerais.

\footnotetext{
${ }^{1}$ Agronomist, Master in Agricultural Production Technology, Analyst, Empresa Brasileira de Pesquisa Agropecuária (Embrapa Sede), BrasíliaDF, Brazil, E-mail: aline.zacharias@embrapa.br (ORCID 0000-0002-3094-6345)

${ }^{2}$ Agronomist, $\mathrm{PhD}$ in Genetics and Plant Breeding, Researcher, Empresa Brasileira de Pesquisa Agropecuária (Embrapa Cerrados), PlanaltinaDF, Brazil, E-mail: fabio.faleiro@embrapa.br (ORCID 0000-0001-8901-6428)

${ }^{3}$ Agronomist, Master in Genetics and Plant Breeding, Teacher, Institute of Agricultural Sciences, Universidade Federal de Uberlândia (UFU), Uberlândia-MG, Brazil, E-mail: gabriellaqueirozalmeida@hotmail.com (ORCID 0000-0002-0340-7346)
} 


\section{Introduction}

Fruit growing in Brazil has been one of the prominent sectors of agribusiness. With a wide diversity of species grown throughout the country and under different edaphoclimatic conditions, the fruit production achieves significant outcomes generating business and jobs opportunities. Regardless of the type of producer (small, average, and large) and investment capacity, the business vision and use of technologies are fundamental for its sustainability.

The average passion fruit yield in Brazil has been around $14 \mathrm{t} \mathrm{ha}^{-1}$ year-1 (IBGE, 2020), although it varies widely among producers in different states and crop systems adopted by the producers. These differences are even greater when considering the profile of producers and also the productive potential of cultivars genetically improved that reaches $60 \mathrm{tha}^{-1}$ year $^{-1}$ in open fields and 110 $\mathrm{t} \mathrm{ha}^{-1}$ year $^{-1}$ in a greenhouse (CAVICHIOLI et al., 2011; JESUS et al., 2018; GONTIJO et al., 2019).

According to data collected by IBGE (2020), the state of Minas Gerais in 2018 showed the fifth largest production of passion fruit in the country, with 31,500 tons in a harvested area of 2,135 ha. Passion fruit cultivation in the mesoregion of the Triângulo Mineiro/Alto Paranaíba is significant and contributes to about $30 \%$ of the volume produced in this state. The crop is driven by companies that are considered one of the main players in the market of ready-to-consume concentrated juices and pulps. The plant located in Araguari (state of Minas Gerais) has the capacity to process up to 100 tons of passion fruit juice a day (ABIR, 2020).

Furthermore, the second largest distribution center of vegetables and fruits statewide is also located in the Triângulo Mineiro region. In 2018, this distribution center called Central de Abastecimento (Ceasa) in Uberlândia/ state of Minas Gerais commercialized a volume of 255,000 tons of fruits and vegetables equivalent to nearly R $\$ 580$ million (CEASAMINAS, 2020). According to Conab (2020), 1,270 tons of passion fruit were sold by CeasaUberlândia in 2018, with $75 \%$ of the fruits grown by producers in the Triângulo Mineiro.

According to Joint Normative Instruction number 2/2018 (ANVISA, 2020), the producer of passion fruit should prioritize the quality of the fruits in order to meet the new reality of the market and regulations to track fresh vegetables, for monitoring and controlling pesticides residues. The use of proper technologies, adequate management of orchards, improvement of post-harvest treatments, cold storage and modern transportation and logistics are required to reach this goal.

As stated by Campos and Carvalho (2011), local production arrangements involve the participation and interaction of several factors that after being identified and analyzed will guide how the interventions in production chains can be more effective. Rocha et al. (2016) showed that the process of evaluation or diagnosis includes the demands and opportunities forecasting method. The authors emphasize that diagnosing a determined situation is to focus on the behavior of producers in relation to the object of interest, which in this present work was the passion fruit cultivation. Once the problems of the producers are identified, the technical-scientific explanations of agronomic, environmental, economic, and social nature should be presented, working as a guidance or clarification to solve those issues.

The purpose of this study was to evaluate the profile of producers and adoption of technologies in the system of passion fruit production and commercialization in the Triângulo Mineiro in order to identify bottlenecks, threats and opportunities that affect the competition of this important production hub.

\section{Material and methods}

The methodology adopted in this study was based on the logical model proposed by Rocha et al. (2018), using as a tool the Behavioral Diagnosis of Productive Activity (BDPAD) to identify problems and solutions associated to rural producers in relation to the activity they perform (Figure 1).

In order to do so, the following outcome indicators were used: knowledge of several tasks involved in the production system; motivations that trigger the producers to choose certain production activity; actions they take to produce and the outcomes obtained in that activity.

The research was carried out from February 2018 to June 2019 with passion fruit producers from the mesoregion of the Triângulo Mineiro, located in eight cities: Araguari, Estrela do Sul, Indianópolis, Monte Alegre de Minas, Monte Carmelo, Pedrinópolis, Prata and Uberlândia. The cities were chosen based on the importance of passion fruit cultivation in the state of Minas Gerais, according to the database from IBGE (2020), which represented $14 \%$ of the state production.

The quasi-experimental design used was based on the rural properties covered by Empresa de Assistência Técnica e Extensão Rural do Estado de Minas Gerais (Technical Assistance and Rural Extension Company of the State of Minas Gerais - Emater-MG) in each municipality, with a simple random sampling. Only producers growing passion fruits in areas equal to or larger than 0.1 ha were selected for this study, with a total of 22 participants, sampling error of $\pm 10 \%$ and a $95 \%$ confidence level. 


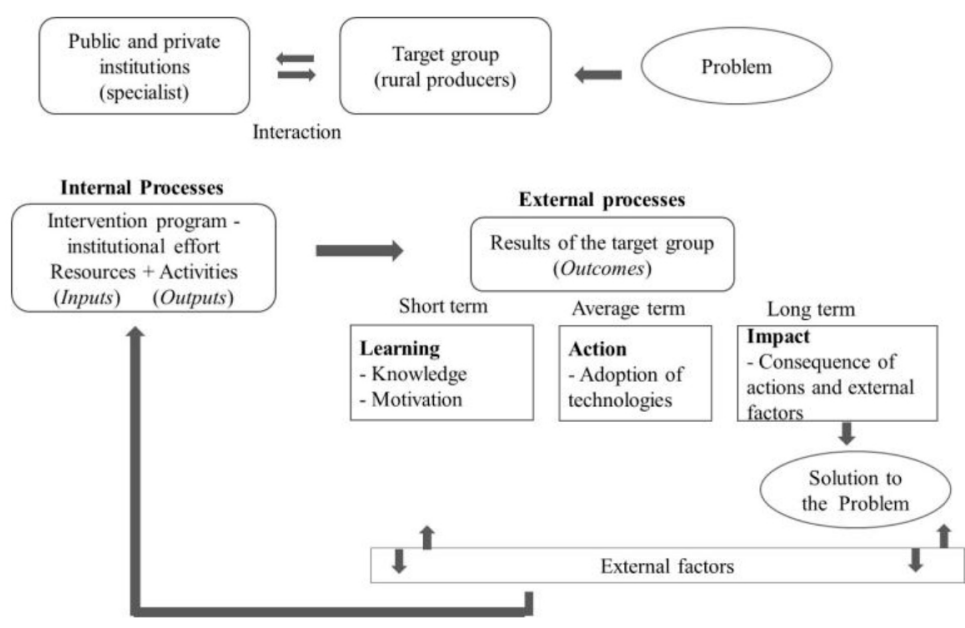

Figure 1. Logical data model of Rocha et al. (2018) with intervention and outcome indicators in short, intermediate, and long term.

A semi-structured questionnaire divided in five blocks of information was developed to collect the primary data: 1 - Characterization of the property and cultivation system; 2 - Knowledge (learning about passion fruit, soil, plant health, harvest, post-harvest and sale); 3 - Motivation (personal, social and situational); 4 - Action (techniques and practices adopted for planting, management, harvesting, pest and disease control, marketing venue, labor used, cultivars); and 5 - Impact (production in recent years, duration of the production cycle, percentage of losses, infestation of pests and diseases, weather conditions, profitability, permanence in the activity), in addition to the measurement of sociodemographic characteristics related to the participant.

The Bardin's model (BARDIN, 2011) was used for content analysis of open-ended responses based on the data classification process by identifying the Elementary Context Units (ECA). Qualitative and quantitative data were listed in a table, using nominal and ratio scale, and submitted to the descriptive analysis by percentage.

Afterwards, eight variables were selected to perform the multivariate analysis of the action and impact indicators (pollination, irrigation, total area, production area, passion fruit cultivation area, area by plant, years of experience and average productivity). Based on the generated Gower's distance matrix (GOWER, 1971), the hierarchical clustering analysis were performed using the UPGMA (Unweighted Paired Group Method using Arithmetic Averages). From the distance matrix and dendrogram, the cophenetic correlation was obtained to verify the reliability of the method. The "optimal" number of groups was defined by the Mojena criterion (FERREIRA, 2011), with the constant value $k$ equal to 1.25 , as suggested by Milligan and Cooper (1985). The R software was used to perform the analysis (2015).
The Student's $t$-test with a 5\% significance level was used to compare the mean yield obtained by the passion fruit producers included in the sample with published by the IBGE for the mesoregion of Triângulo Mineiro (13.9 $\mathrm{t} \mathrm{ha}^{-1}$ year $\left.{ }^{-1}\right)$.

\section{Results and discussion}

\section{Producers profile}

It was observed that $63.6 \%$ of the producers owned the rural property, $91 \%$ were males and the ages of $36.4 \%$ of them ranged from 20 to 37 years (Table 1), indicating that the cultivation of passion fruit is an important activity to keep farmers in the field, avoiding the rural exodus. It also showed that young producers consider the cultivation of passion fruit in the Triângulo Mineiro an opportunity, corroborating the data obtained by Emater-MG (2020) on the profile of rural producers in Minas Gerais. Although the percentage of females is lower, they participate in these activities because the crop is a family business.

The present study found different levels of education among the producers, however $41 \%$ stated to have fundamental education. This information should be considered when technical assistance is provided so that the language and means of communication are appropriate. Furthermore, $23 \%$ of the producers said they started or completed college, evidencing that the cultivation of passion fruit can generate employment and satisfactory income, as an alternative to the difficulty of including these professionals in the job market. 
Table 1. Profile of passion fruit producers in the mesoregion of the Triângulo Mineiro.

\begin{tabular}{llllll}
\hline \multicolumn{1}{c}{ Identification } & \multicolumn{1}{c}{ Number (\%) } & \multicolumn{1}{c}{ Origin } & \multicolumn{1}{c}{ Number (\%) } & \multicolumn{1}{c}{ Gender } & Number (\%) \\
\hline In settlements & $5(22.7)$ & Minas Gerais & $17(77.3)$ & Female & $2(9.1)$ \\
Tenant & $3(13.6)$ & São Paulo & $1(4.5)$ & Male & $22(90.9)$ \\
Owner & $14(63.6)$ & Paraná & $4(18.2)$ & & \\
\hline Age group (years) & Number (\%) & Education & Number (\%) & Experience (years) & Number (\%) \\
\hline $20-37$ & $8(36.4)$ & Informal education & $2(9.1)$ & $0.5-1.0$ & $3(13.6)$ \\
$38-51$ & $4(18.2)$ & Elementary & $9(40.9)$ & $1.1-5.0$ & $12(54.5)$ \\
$52-66$ & $6(27.3)$ & education & $6(27.3)$ & $5.1-10.0$ & $5(22.7)$ \\
$67-89$ & $4(18.2)$ & Unigh school & $5(22.7)$ & $10.1-20.0$ & $2(9.1)$ \\
\hline
\end{tabular}

A large number of producers mentioned they had little experience regarding growing passion fruit, considering that $68 \%$ of the participants had been growing passion fruit for less than five years. These producers came from other agricultural activities and are searching for income diversification. About $32 \%$ of the participants stated to have more than five years of experience working with passion fruit crop. According to Faleiro et al. (2019), actions to promote technical and entrepreneurship training are needed to increase the permanence of farmers with less experience in this agriculture activity.

\section{Characterization of properties}

The average area of the properties was 18.8 hectares, with $55 \%$ of the participants owning a total area between 10 and 30 hectares. More than $95 \%$ of the producers grew passion fruit in areas up to 5 hectares, evidencing that this crop can be profitable in small pieces of land. Furthermore, as most producers work in a family regimen, larger orchards would demand more labor. In many Brazilian regions, including the Triângulo Mineiro, the supply of labor is low.

The economic study performed by Pimentel et al. (2009) in the Zona da Mata Mineira region, where there is also an industrial fruit processing park, concluded that passion fruit cultivation is a profitable and fast-returning activity, being considered a good investment alternative in 1-5 ha areas.

The cultivation system for all species of passion fruit (sour, sweet and wild) adopted in the Triângulo Mineiro is open fields, being $95.5 \%$ grown in a conventional way, using pesticides and chemical fertilization. However, there was a tendency to change this scenario, with some producers adopting an organic system, encouraged by the local agroindustry that serves the foreign market. Therefore, it is believed that more passion fruit orchards located in the region will transition from conventional to organic systems, increasing the demand for more research and development actions and also technology transfer.

The reasons reported by the producers for not adopting a greenhouse system was mainly due to the high cost, although 5\% were not aware they could use this production system for passion fruit. The cultivation of passion fruit in greenhouses is a reality in the Federal District, representing about $9 \%$ of the production system in this region, being considered pioneers (FALEIRO et al., 2019). They take advantage of the existing infrastructure to grow vegetables and flowers.

Besides growing passion fruit, the producers in the state of Minas Gerais have other agricultural activities to diversify income, mainly the cultivation of vegetables (54.5\% of the producers), other fruit species such as citrus and banana $(27.3 \%)$ and grains $(27.3 \%)$. Coffee is also a very relevant cultivation in the region evaluated, especially in Araguari, where $9.1 \%$ of the producers have been growing passion fruit to replace older coffee plants, serving as a staking system for passion fruit, saving money with stakes and wires during the planting.

\section{Knowledge and motivation of producers}

The results of technical quality presented by passion fruit producers in the Triângulo Mineiro compared with the type of seeds and seedlings chosen, management practices, identification of pests and diseases and sale are detailed in Table 2.

The largest learning gaps were found in topics related to phytosanitary management. At least $32 \%$ of the producers find it difficult to recognize and differentiate major pests and diseases. It was also noticed that $68.2 \%$ did not know how to answer the questions about Integrated Pest Management (IPM). Similar results were found by Faleiro et al. (2019).

Therefore, tools that allow a simpler and more agile diagnosis of pests and diseases allowing control alternatives based on the integrated management need to be promoted. The concept, principles, and different strategies (cultural, biological, genetics and chemical) should be discussed with these producers. In this sense, in 2019 Embrapa and its partners developed a free cell app (AgroPragas Maracujá) with information related to the main pests and diseases of the passion fruit cultivation and ways to control them (EMBRAPA, 2020a).

As for the most stated personal reasons that led producers to choose the passion fruit cultivation (Table 3), it was observed that the percentage of advantages (83.4\%) was slightly superior than the percentage of disadvantages (72.9\%), which might indicate a higher risk of having them staying in this produce activity. 
Table 2. General advice attributed to the knowledge ${ }^{(1)}$ of passion fruit producers in the Triângulo Mineiro regarding the topics associated to passion fruit cultivation in June 2019.

\begin{tabular}{lccccc}
\hline \multicolumn{1}{c}{ Topic } & $\begin{array}{c}\text { Average of } \\
\text { grades }\end{array}$ & $\begin{array}{c}\text { Concept } \\
\text { attributed } \\
\text { to response }\end{array}$ & $\begin{array}{c}\text { Identified } \\
\text { learning gap }\end{array}$ & $\begin{array}{c}\text { Amplitude to be } \\
\text { approached }\end{array}$ & $\begin{array}{c}\text { Indicated } \\
\text { intervention level }\end{array}$ \\
\hline $\begin{array}{l}\text { Ideal passion fruit } \\
\text { seedlings }\end{array}$ & 3 & Reasonable & Moderate & Complementary & $\begin{array}{c}\text { Intermediate } \\
\text { Pollination }\end{array}$ \\
$\begin{array}{lcccc}\text { Intermediate to } \\
\text { advanced }\end{array}$ \\
$\begin{array}{l}\text { Formative pruning } \\
\begin{array}{l}\text { Identification of } \\
\text { passion fruit pests }\end{array}\end{array}$ & 4 & Sufficient & Superficial & Specific & $\begin{array}{c}\text { Intermediate to } \\
\text { advanced }\end{array}$ \\
$\begin{array}{l}\text { Identification of } \\
\text { passion fruit diseases }\end{array}$ & 2 & Insufficient & Severe & Wide (in depth) & $\begin{array}{c}\text { Introductory to } \\
\text { basic }\end{array}$ \\
$\begin{array}{l}\text { Integrated pest } \\
\text { management (IPM) }\end{array}$ & 1 & Precarious & Super severe & Wide (in depth) & $\begin{array}{c}\text { Introductory to } \\
\text { basic }\end{array}$ \\
$\begin{array}{l}\text { Value aggregation of } \\
\text { passion fruit }\end{array}$ & 3 & Reasonable & Moderate & Complementary & Intermediary \\
\hline
\end{tabular}

(1) The evaluation criteria mentioned in the top of the Table were based on the analysis plan applied to the Behavioral Diagnosis of Productive Activity (ROCHA et al., 2018). Grade 0 - 1: poor answer; Grade 2: insufficient answer; Grade 3: reasonable answer; Grade 4: sufficient answer; and Grade 5: more complete answer.

Table 3. Indicators of personal motivation, modal salient behavioral beliefs, and response rate from the passion fruit producers in the Triângulo Mineiro, in June 2019.

\begin{tabular}{clcc}
\hline Personal motivation & Modal salient behavioral beliefs & $\boldsymbol{f}$ & $\mathbf{\%}$ \\
\hline \multirow{5}{*}{ Advantages } & 1 - Easy commercialization & 15 & 27.8 \\
& 2 - Profit & 12 & 22.2 \\
& 3 - All year around production and sale & 7 & 13.0 \\
& 4 - Easy access to seeds and seedlings & 6 & 11.1 \\
& 5 - Assurance that the industry will buy the production & 5 & 9.3 \\
& Total & 45 & 83.4 \\
\hline & 1 - Low sale price & 10 & 27.0 \\
& 2 - A lot of labor required & 9 & 24.3 \\
Disadvantages & 3 - High infestation of pests and diseases & 8 & 21.6 \\
& 4 - No disadvantage & 3 & $(-) 8.1$ \\
& 5 - High cost of production & 3 & 8.1 \\
& Total & 33 & 72.9 \\
\hline
\end{tabular}

The economic factors related to the easiness of commercialization and profit generation were considered the main benefits of this type of crop in the area evaluated in this study, with $50 \%$ of the responses. This result might be attributed to the fact that the properties are close to big urban centers and produce commercialization centers as well as the partnership with the agricultural industry, representing the main facilities, with $26 \%$ of the answers referring to positive indicators of situational motivation (opportunities of outdoor environment).

As for disadvantages observed by the producers, the low sale price was the most common disadvantage mentioned, with $27 \%$ (Table 3 ) of the producers saying they were not happy about the price paid by the industry, being several times lower than the price of the fresh fruit sold at farmers markets or grocery stores. It is important to emphasize that the need for a lot of labor was mentioned by $24.3 \%$ of the producers as a disadvantage of this kind of crop. Some producers $(15.4 \%)$ stated the lack of qualified labor as a difficulty to grow passion fruit in the Triângulo Mineiro. However, 38.5\% considered pests and disease control as the main threat to the external environment for this activity.

It is fundamental to highlight that access to technologies and supplies was indicated both as an easy $(13.3 \%)$ and difficult $(15.4 \%)$ aspect of the cultivation when measuring the situational motivation. It was found that producers who were associated to juice industry get 
a technological package to meet the market requirements and has constant technical assistance. On the other hand, producers that only sell their produce to grocery stores and farmer markets do not have access to technical assistance, making it difficult to obtain adequate technologies for the agricultural production system.

In relation to people or institutions that support or that could support (social motivation) this agricultural activity, $36.8 \%$ of the producers stated that the juice industry is the one that most purchase passion fruit in the region and can strongly influence them to remain in this activity. Furthermore, $21 \%$ of them mention they wish Emater-MG as well as the city government and research institutions like Embrapa, could provide them more support, showing the importance of having public programs to encourage passion fruit production in the Triângulo Mineiro.

Adoption of technologies and impacts on production

Fifty-nine percent of the producers buy the seedlings in nurseries registered at the Ministry of Agriculture, Livestock and Supply of Brazil (Ministério da Agricultura, Pecuária e Abastecimento - Mapa), with only $13.6 \%$ producing their own seedling from seeds purchased in stores. This information shows that the producers are employing the adequate procedure, since they are using seedlings presenting genetic origin and phytosanitary quality purchased in registered nurseries. It is important to emphasize the partnership between the agricultural industry and the nursery responsible for the commercialization of seedlings and producers.

When evaluating the production system, it was found that the vast majority (86.4\%) of producers do not grow passion fruit using intercropping or crop rotation. Several studies have shown the advantages in diversifying productive species in the same area, since it promotes improvements in soil structure and biology, increasing organic matter contents (ARAUJO NETO et al., 2014; GUIMARÃES, 2016). However, attention should be paid to the appropriate phytosanitary management of intercropped species so that passion fruit tree will not to be harmed.

Regarding soil nutrition, before planting the seedlings $77 \%$ of the producers perform soil analysis and $91 \%$ the acidity correction, being considered the correct procedure to optimize the use of fertilizers and increase the efficiency in the absorption of nutrients, especially in soils in the savannah. All producers use fertilizers with nitrogen $(\mathrm{N})$, phosphorus $(\mathrm{P})$ and potassium $(\mathrm{K})$ sources, $87 \%$ of them put the fertilizer in the pit and the remaining in the total area. The most used organic fertilizer used for this crop is cattle manure (77.3\%) since it is easily found in most of the properties and $31.8 \%$ use poultry litter.

Top dressing fertilization is made fortnightly, especially with potassium chloride and urea. However, $59.1 \%$ of the participants use broadcast application and not incorporated, which is not being considered proper since it results in a higher loss of nutrients through lixiviation or volatilization (SANGOI et al., 2003). Fertigation was used by $22.7 \%$ of the producers allowing the improvement of the fertilizer efficiency.

The most adopted plant management system by the producers in the state of Minas Gerais is the vertical espalier with only one wire (1.5-2.0 meter high). This system is the most popular in the regions producing passion fruit because it is easy to build and execute (ZACHARIAS et al., 2016). Producers also use training pruning and form the "curtain" (productive tertiary branches), having an influence on the productive characteristics of plants, as observed by other authors (ALBUQUERQUE et al., 2009; HAFLE et al., 2009).

To control pests and diseases, $95.5 \%$ of the producers use pesticides (insecticides, acaricides, fungicides and bactericides) with monthly applications (45.5\%), but $36.4 \%$ use them weekly, indicating the need for training on how to manage pesticides at the correct time, that is, when pests and diseases reach levels of economic damage.

It was found that many producers used pesticides that were not registered for passion fruit, such as the insecticides Lannate ${ }^{\circledR}$ (a. i. Metomil) and Karate ${ }^{\circledR}$ (a. i. Lambda-Cialotrina) and the acaricide Vertimec ${ }^{\circledR}$ (a. i. Abamectin). This behavior indicates the lack of knowledge and technical follow-up, also showing there is a restrict number of products registered for this specific crop. Currently, there are 47 pesticides products and a microbiological product in the market that are registered for phytosanitary management of the passion fruit, covering little diversity of active principles and use indication for pests and diseases of this crop (AGROFIT, 2020). It was noticed that the users of the app 'AgroPragas Maracujá' have access to an updated list of phytosanitary products registered at the Ministry of Agriculture, Livestock and Supply of Brazil for this fruit (EMBRAPA, 2020a), that might help the correct use by the producers.

Another important technique for the production of sour passion fruit is the manual pollination. Although only $68 \%$ of producers use it, this technique should be used by all of them to increase the production and filling period of fruits. According to Lima (2005), man-made pollination is more efficient than that performed by insects, such as carpenter bees (Xylocopa spp.), significantly increasing the fruit setting by more than $50 \%$ and the quality of the fruits.

When analyzing the number of people involved in passion fruit cultivation and the time spent with cultivation management, it was noticed that $59.1 \%$ of the properties have family members working together. These people 
used to work up to 3 hours/day, but, depending on the cultivation phase, they would spend up to 10 hours a day. About $23 \%$ of the producers interviewed hired daily workers for the crop management, in general for a period of 1-2 months a year, during the peaks of production and harvesting.

As for the commercialization of passion fruits in the Triângulo Mineiro region, all producers sell in natura (fresh) passion fruit, with no processing. About $64 \%$ of them sell the fruits to juice industries and $36.4 \%$ are purchased by Ceasa (state of Minas Gerais) in Uberlândia and Uberaba (Table 4). According to the database collected by Conab, in $2019,75 \%$ of the passion fruit commercialized at Ceasa in Uberlândia came from the state of Minas Gerais, where more than $80 \%$ came from the city of Araguari, equivalent to $680.000 \mathrm{~kg}$ of fruits (CONAB, 2020).

Table 4. Passion fruit production destination, according to the type and sale location in the Triângulo Mineiro, 2019.

\begin{tabular}{lll}
\hline Product destination & $\boldsymbol{f}$ & $\mathbf{\%}$ \\
\hline Wholesale - Industry & 14 & 63.6 \\
Wholesale - Ceasa/state of Minas Gerais & 8 & 36.4 \\
Wholesale - Government & 2 & 9.1 \\
Wholesale - Supermarket/Grocery stores & 2 & 9.1 \\
Retail - Farmers markets & 2 & 9.1 \\
Retail - Direct to the buyer & 2 & 4.5 \\
\hline
\end{tabular}

In other regions where there are no agro-industrial facilities for fruit processing, passion fruit can be sold in different types of business. In the Federal District, 37\% of the production is sold as pulp since producers can get a higher value aggregation. Regarding the in natura (fresh) fruit, $37 \%$ is purchased by wholesale middlemen, $24 \%$ is sold in farmers markets by the producer and $23 \%$ to direct retail to the consumer (FALEIRO et al., 2019).

The average price of passion fruit sold at CeasaMG - Uberaba, from January 2015 to December 2019, was $\mathrm{R} \$ 3.97 / \mathrm{kg}$ (CONAB, 2020). Prices varied during the harvest and off-season periods, but the producers still got a good price for their production when compared to other fruits produced in the region, such as banana ( $\mathrm{R} \$$ $1.95 / \mathrm{kg})$, orange ( $\mathrm{R} \$ 1.45 / \mathrm{kg})$ and acid lime ( $\mathrm{R} \$ 2.39 / \mathrm{kg})$. In terms of price paid by juice industries, despite being a value below the wholesale market, on average R $\$ 1.98$ to $\mathrm{R} \$ 2.20 / \mathrm{kg}$, producers have the guarantee of selling all their production.

Considering the indicators for impact of actions and environmental factors on productive activity, the analysis of technological problems that need to be changed in the future through an intervention program was performed.

One of these indicators is the production cycle. The duration of the production cycle of passion fruit orchards in the Triângulo Mineiro ranged from one to two years. This shorter longevity may be due to phytosanitary problems that lead to earlier plant renewal, as reported by Sampaio et al. (2008). The cultivation of passion fruit as an annual plant is common in many regions of Brazil, such as the South and Northeast.

In the case of passion fruit as an annual crop, researches about alternatives for crop rotation are important, considering the need to reuse training structures for plants such as the trellis and espalier, as they represent a high cost of initial investment, as analyzed by Araújo et al. (2005) and Mendonça et al. (2018), that would become diluted over the years.

The most grown cultivar in the region is $\mathrm{FB}$ 300 , being planted in $68.2 \%$ of the properties and also being recommended by the local industry because of the partnership between the nurseries and also the fruit quality for juices. Other cultivars more recently positioned in the market have already been adopted. It was found that $13.6 \%$ of the producers grow BRS Gigante Amarelo (sour passion fruit with high productive potential), $9.1 \%$ grow the BRS Rubi do Cerrado (sour passion fruit with high productive potential for juice), in addition to $4.5 \%$ planting the wild passion fruit cultivar BRS Pérola do Cerrado, indicated for the special fruit segment (EMBRAPA, 2020b).

It was verified that $77 \%$ of the producers grew more than one cultivar in the same area, showing interest for new technologies and different markets. Several factors influence the choice of the cultivar such as a closer distance from the area where the fruit was grown to the main commercialization centers, cultivar fitness and the availability of seeds and local seedlings. Competition trials in different regions are extremely important to promote the adoption of new cultivars (REIS et al., 2018).

More than $30 \%$ of the producers were not able to inform the current and past years production. Because passion fruit cultivation is the main income for some producers, it is fundamental to obtain and register these data throughout the years in order to plan the budget and seek improvements to increase the production. In this case, one example of intervention would be courses and training in the area of entrepreneurship and finance provided by local institutions, such as Sebrae Minas and FAEMG/Senar.

In 2018 and 2019, the statistical indicators of the 
average area of passion fruit cultivation and the average production obtained by the producers of the Triângulo Mineiro were 1.9 ha and $26.5 \mathrm{t}$, respectively (Table 5). When analyzing the production data of those who reported, about $36 \%$ had a productivity of 10 to $20 \mathrm{t} \mathrm{ha}^{-1}$ year $^{-1}$ and the overall average was $17 \mathrm{t} \mathrm{ha}^{-1}$ year $^{-1}$. According to the data provided by Produção Agrícola Municipal (IBGE, 2020), in 2018, the average national passion fruit productivity was $14 \mathrm{t} \mathrm{ha}^{-1}$ year ${ }^{-1}$, in the state of Minas Gerais it was $14.8 \mathrm{t} \mathrm{ha}^{-1}$ year ${ }^{-1}$ and in the mesoregion of the Triângulo Mineiro, the yield was $13.9 \mathrm{t} \mathrm{ha}^{-1}$ year ${ }^{-1}$. It was concluded that the average yield of this sample cannot be considered statistically higher than $13.9 \mathrm{t} \mathrm{ha}^{-1}$ year $^{-1}$.

Table 5. Statistical indicators of cultivation area (ha) and production of passion fruit (t) in the Triângulo Mineiro region, in the period of 2018 and 2019.

\begin{tabular}{llll}
\hline \multicolumn{2}{l}{ Passion fruit cultivation area (ha) } & \multicolumn{2}{l}{ Passion fruit production (ton) } \\
\hline Indicator & Value & Indicator & Value \\
\hline Total area & 41.7 & Total production & 397.9 \\
\hline Maximum area & 6.0 & Maximum production & 60 \\
\hline Minimum area & 0.1 & Minimum production & 1.2 \\
\hline Average area & 1.9 & Average production & 26.5 \\
\hline Median area & 1.3 & Median production & 24 \\
\hline
\end{tabular}

Figure 2 shows that in recent years, the main damage caused to passion fruit in the region was caused by bees, bacterial spot (Xanthomonas axonopodis pv. passiflorae), drought and hail. The stingless bee (Trigona sp) negatively affects the orchards by damaging new leaves and floral bud when extracting nectar and collecting pollen. As for the Apis mellifera bee when collecting the pollen, it does not pollinate the plant because of its small size, causing the buds to fall (OLIVEIRA; FRIZZAS, 2014). The bacterial spot is responsible for large losses because it is difficult to be controlled under high temperature and humidity (ISHIDA; HALFELD-VIEIRA, 2009).

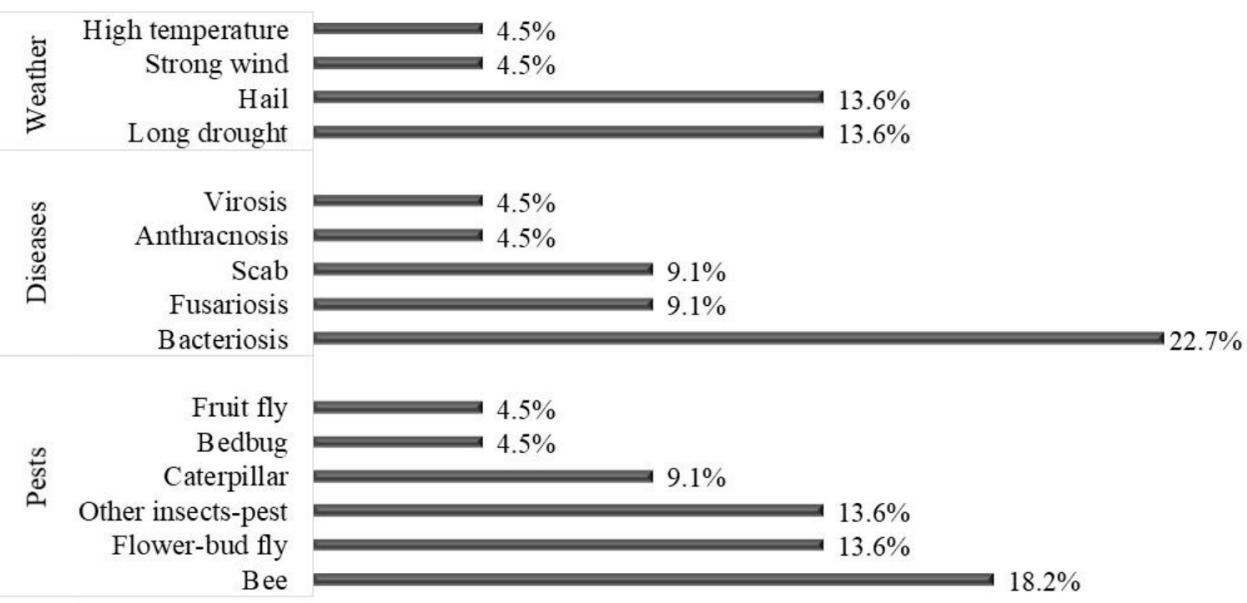

Figure 2. Weather events, diseases, and pests that caused damage to passion fruit from 2017 to 2019 in the Triângulo Mineiro region (\% of answers). 
The family income for $22.7 \%$ of the producers comes from $20-30 \%$ of the passion fruit sale. Only $4.5 \%$ of the producers make their living just by growing passion fruit. When comparing the profitability in 2019 and 2018, $31.8 \%$ of the producers have not made yet a profit since this is the first year growing passion fruit, while $22.7 \%$ considered to have decreased. Based on the information collected, the decrease of profitability was caused by the lower price of the fruit, higher cost of agricultural supplies and lower productivity of the orchard.

When asked about the area they will grow passion fruit next year, $59.1 \%$ of the producers stated they will keep the same area as before mainly because they do not own a larger piece of land to expand, although they are happy with this kind of crop. On the other hand, 27.3\% feel like using a larger piece of land to grow this crop because of its profitability and because it is easy to sell the fruit. Only $13.6 \%$ will stop growing passion fruit mainly because of the difficulty in finding labor. Most of the participants stated they plan to remain growing this fruit because it has been a good alternative in the diversification of income for rural producers in the Triângulo Mineiro.

When comparing the interviewed producers, it was found that there is a similarity in $68.2 \%$ of the sample, according to the dendrogram obtained by the UPGMA method, where the cophenetic correlation was 0.7469 (Figure 3). When applying the cut-off based on the Mojena's method, it showed the existence of three statistically distinct clusters.

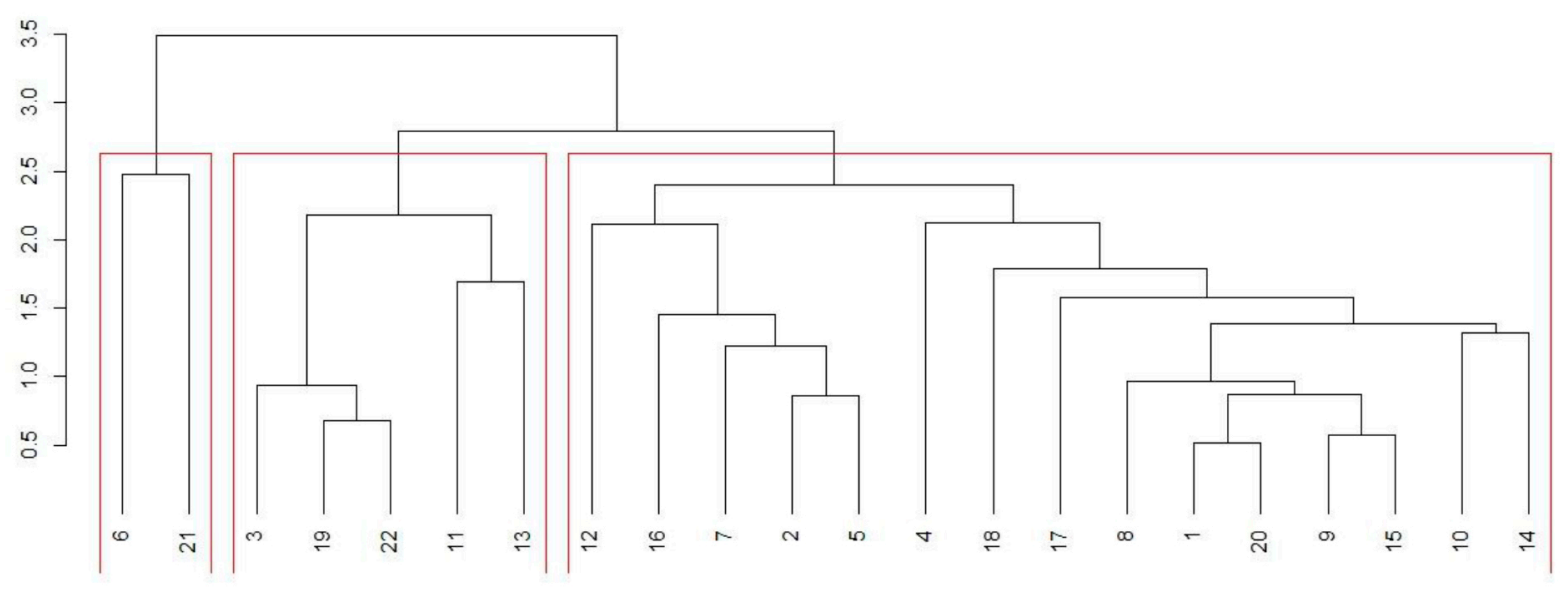

hclust (* "average")

Figure 3. Dissimilarity dendrogram among 22 passion fruit producers from the Triângulo Mineiro region, obtained by the UPGMA method based on the Gower's algorithm $(k=1.25)$, from two qualitative and six quantitative features. Uberlândia-MG, 2019.

Group I was constituted of two producers that did not use hand pollination neither used an irrigation system, however last year they showed a $20 \mathrm{t} \mathrm{ha}^{-1}$ year ${ }^{-1}$ yield, being higher than the average production on the region. Group II included 5 producers who did not adopt hand pollination but used irrigation and achieved a lower yield than the average (11 t ha- year $\left.^{-1}\right)$. Group III included 15 producers who adopted manual pollination, but not all of them used irrigation systems and the average yield of the group was $18 \mathrm{t} \mathrm{ha}^{-1}$ year $^{-1}$, with producers reaching up to $50 \mathrm{t} \mathrm{ha}^{-1}$ year $^{-1}$. Thus, the pollination variable had a greater influence on the construction of clusters. For this sample, the time of experience, spacing between plants and the cultivated area of passion fruit did not show a high correlation with the fruit yield.

\section{Conclusions}

The cultivation of passion fruit in the Triângulo Mineiro is mainly performed by young producers with little experience and who uses a small area of the property for this species, diversifying the income with other agricultural activities.

The local juice industry has been important to encourage the passion fruit production, being one of the places that purchases those fruits. Producers tend to remain in this business if there is a proper technical support and guaranteed commercialization, in addition to the opportunity to open new markets.

Because producers have not been adopting new technologies and more sustainable agricultural practices, a higher integration among the institutions responsible for the interventions and the public of interest is required. 

KOLLN, F.T.; ANDRADE NETO, R.C. Atividade

Courses and training for integrated pest and disease management will help to achieve better productive results, as well as management of small rural businesses. In addition, the need for different interventions should be considered for each identified cluster.

The results found in the present study might contribute to the development of more adequate environments to agricultural innovation and improve passion fruit production systems in the region, through future research and development, technological transference, public politics and interventions in the productive sector, allowing the expansion of this crop.

\section{References}

ABIR - Associação Brasileira das Indústrias de Refrigerantes e de Bebidas Não Alcoólicas. Dados do setor. Brasília, DF, 2020. Disponível em: https://abir. org.br/associado/britvic-ebba/. Acesso em: 18 fev. 2020.

AGROFIT - Sistema de Agrotóxicos Fitossanitário. Ministério da Agricultura, Pecuária e Abastecimento. Registro de agrotóxicos e afins. Brasília, DF, 2020. Disponível em: http://agrofit.agricultura.gov.br/agrofit cons/principal agrofit cons. Acesso em: 25 fev. 2020.

ALBUQUERQUE, I.D.; CAVALCANTE, L.F.; LOPES, E.B.; ARAÚJO, R.D.C.; BRITO, C.D. Efeito de diferentes podas em ramos produtivos no rendimento do maracujazeiro amarelo. Engenharia Ambiental, Espírito Santo do Pinhal, v.6, n.3, 2009.

ALMEIDA, L.C.C. Doenças do Maracujá. In: OLIVEIRA, S.M.A.; TERÃO, D.; DANTAS, S.A.F.; TAVARES, S.C.C.H. (ed.). Patologia pós colheita: frutas, olerícolas e ornamentais tropicais. Brasília, DF: Embrapa Informações Tecnológicas, 2006. p.776-799.

ANVISA - Agência Nacional de Vigilância Sanitária. Legislação. Brasília, 2020. Disponível em: Acesso em: 06 abr. 2020.

ARAÚJO, J.L.P.; ARAÚJO, E.P.; CORREIA, R.C. Análise do custo de produção e rentabilidade do maracujá explorado na região do submédio São Francisco. Petrolina: Ministério da Agricultura, Pecuária e Abastecimento, 2005. (Comunicado Técnico 122). Disponível em: http://www.cpatsa.embrapa.br/public eletronica/downloads/COT122.pdf. Acesso em: 06 abr. 2020. biológica de solo sob cultivo múltiplo de maracujá, abacaxi, milho, mandioca e plantas de cobertura. Revista Ciência Agronômica, Fortaleza, v.45, n.4, p.650-658, 2014.

BARDIN, L. Análise de conteúdo. São Paulo: Edições 70, 2011.

CAMPOS, K.C.; CARVALHO, F.M.A. Índice de inovação: hierarquização dos produtores do arranjo produtivo local de fruticultura irrigada, estado do Ceará. Revista de Economia e Sociologia Rural, Brasília, v.49, n.3, p.741-770, 2011.

CAVICHIOLI, J.C.; CORRÊA, L. de S.; GARCIA, M.J. de M.; FISCHER, I.H. Desenvolvimento, produtividade e sobrevivência de maracujazeiro-amarelo enxertado e cultivado em área com histórico de morte prematura de plantas. Revista Brasileira de Fruticultura, Jaboticabal, v.33, n. 2, p. 567-574, 2011.

CEASAMINAS - Centrais de Abastecimento de Minas Gerais S.A. Ceasa em números. Belo Horizonte, 2018. Disponível em: http://minas1.ceasa. mg.gov.br/ceasainternet/lib/file/docceasanumeros/ Informacoesdasunidades2018.pdf. Acesso em: 10 mar. 2020.

CONAB - Companhia Nacional de Abastecimento. Informações de mercados de abastecimento do Brasil. Programa brasileiro de modernização do mercado hortigranjeiro. Brasília, DF, 2020. Disponível em: https:// www.conab.gov.br/info-agro/hortigranjeiros-prohort/. Acesso em: 10 mar. 2020.

EMATER-MG - Empresa de Assistência Técnica e Extensão Rural de Minas Gerais. Perfil da agricultura familiar de Minas Gerais. Belo Horizonte, 2014. Disponível em: http://www.agricultura.mg.gov.br/images/ files/Perfil $\% 20 \mathrm{da} \% 20$ Agricultura $\% 20$ Familiar $\% 20 \mathrm{v} 2$.pdf. Acesso em: 20 jan. 2020.

EMBRAPA- Empresa Brasileira de Pesquisa Agropecuária. Aplicativo AgroPragas maracujá. Guia de identificação e controle de pragas. Brasília, DF, 2020. Disponível em: https://ainfo.cnptia.embrapa.br/digital/bitstream/ item/204951/1/folder-AGROPRAGAS-AINFO.pdf. Acesso em: 06 mai. 2020a.

EMBRAPA- Empresa Brasileira de Pesquisa Agropecuária. Cultivares de maracujá. Brasília, DF, 2020. Disponível em: https://www.embrapa.br/cultivar/maracuja. Acesso em: 06 mai. 2020b. 
FALEIRO, F.G.; ROCHA, F.E.C.; GONTIJO, G.M.; ROCHA, L.C.T.R. Maracujá: prospecção de demandas para pesquisa, extensão rural e políticas públicas baseadas na adoção e no impacto de tecnologias. Expedição safra Brasília - maracujá. Brasília, DF: Emater, 2019. v.2, 275 p.

FERREIRA, D.F. Estatística multivariada. Lavras: Ed. UFLA, 2011. v.2, 676p.

GOWER, J. C. A general coefficient of similarity and some of its properties. Biometrics, Washington, v.27, n.4, p.857-874, 1971.

GONTIJO, G.M.; FALEIRO, F.G.; ROCHA, F.E.C.; CARDOSO, F.C.P.; JUNQUEIRA, N.T.V.; LOBATO, B.R.; MENDES, A.C.S. Demandas relacionadas à ação e ao impacto da produção de maracujá no DF: estudo empírico voltado à pesquisa, extensão e política pública. In: FALEIRO, F.G.; ROCHA, F.E.C.; GONTIJO, G.M.;

ROCHA, L.C.T. (ed.) Maracujá: prospecção de demandas para pesquisa, extensão rural e políticas públicas baseadas na adoção e no impacto de tecnologias. Expedição safra Brasília - Maracujá. Brasília, DF: Emater, DF, 2019. v.2, p. $154-255$.

GUIMARÃES, T.G. Produção de maracujá em sistemas consorciados ou de policultivos. In: FALEIRO, F.G; JUNQUEIRA, N.T.V. (ed.). Maracujá: o produtor pergunta, a Embrapa responde. Brasília, DF: Embrapa, 2016. 341 p. (Coleção 500 perguntas, 500 respostas).

HAFLE, O.M.; RAMOS, J.D.; LIMA, L.C.O.; FERREIRA, E.A.; MELO, P.C. Produtividade e qualidade de frutos do maracujazeiro-amarelo submetido à poda de ramos produtivos. Revista Brasileira de Fruticultura, Jaboticabal, v.31, n.3, p.763-770, 2009.

IBGE - Instituto Brasileiro de Geografia e Estatística. Produção agrícola municipal: culturas temporárias e permanentes. Rio de Janeiro, 2020. Disponível em: https:// sidra.ibge.gov.br/pesquisa/pam/tabelas. Acesso em: 06 mar. 2020.

ISHIDA, A.K.N.; HALFELD-VIEIRA, B.A. Manchabacteriana do maracujazeiro (Xanthomonas axonopodis pv.passiflorae): etiologia e estratégias de controle. Belém: Embrapa Amazônia Oriental, 2009. 23p. (Documentos).
JESUS, O.N.; MACHADO, C.F.; JUNGHANS, T.G.; OLIVEIRA, E.J.; GIRARDI, E.A.; FALEIRO, F.G.; ROSA, R.C.C.; SOARES, T.L.; LIMA, L.K.S.; SANTOS, I.S.; SAMPAIO, S.R.; AGUIAR, F.S.; GONÇALVES, Z.S. Recursos genéticos de Passiflora L. na Embrapa: prémelhoramento e melhoramento genético. In: MORERA, M.P.; COSTA, A.M.; FALEIRO, F.G.; CARLOSAMA, A.R.; CARRANZA, C. (ed.) Maracujá: dos recursos genéticos ao desenvolvimento tecnológico. Brasília, DF: ProImpress, 2018. p.17-42.

LIMA, A. A. Aspectos fitotécnicos: desafios da pesquisa. In: FALEIRO, F.G.; JUNQUEIRA, N.T.V.; BRAGA, M.F. (Ed.). Maracujá: germoplasma e melhoramento genético. Planaltina, DF: Embrapa Cerrados, 2005. p.643-677.

MENDONÇA, J.P.;CARNEIRO, V.A.; OLIVEIRA , A .L.R.; TAKEMOTO, S.Y.NOGUEIRA, J.C.M.; Viabilidade econômica da implantação de lavoura de maracujá cultivar brs gigante amarelo. Revista Mirante, Anápolis, v.11, n. 8, 2018.

MILLIGAN, G.W.; COOPER, M.C. An examination of procedures for determining the number of clusters in a data set. Psychometrika, New York, v.50, n.2, p.159179, 1985.

OLIVEIRA, C. M. de; FRIZZAS, M. R. Principais pragas do maracujazeiro amarelo (Passiflora edulis f. flavicarpa Degener) e seu manejo. Planaltina, DF: Embrapa Cerrados, 2014. 43 p. (Documentos, 323).

PIMENTEL, L.D.; SANTOS, C.E.M.; FERREIR, A.C.C.; MARTINS, A.A.; WAGNER JÚNIOR, A.; BRUCKNER, C.H. Custo de produção e rentabilidade do maracujazeiro no mercado agroindustrial da Zona da Mata Mineira. Revista Brasileira de Fruticultura, Jaboticabal, v.31, n.2, p.397-407, 2009.

R Core Team. R: A language and environment for statistical computing. Vienna: R Foundation for Statistical Computing, 2015.

REIS, L.C.; FORESTI, A.C.; RODRIGUES, E.T. Desempenho de cultivares de maracujá (Passiflora edulis f. flavicarpa) no sistema de produção orgânico. Revista de la Facultad de Agronomía, La Plata, v.117, p.253$260,2018$.

ROCHA, F.E.C.; MARCELINO, M.Q.S.; MENDES, A.C.S.; LOBATO, B.R. (ed.). Diagnóstico comportamental da atividade produtiva: método de operacionalização do processo de inovação. Expedição safra Brasília - maracujá. Brasília, DF: Emater/DF, 2018. v.1, $271 \mathrm{p}$. 
ROCHA, F.E.C.; TRÓCCOLI, B.T.; MACHADO, M.S.; SANTOS, J.F. Modelo lógico da transferência de tecnologia no contexto da avaliação de programas. Planaltina: Embrapa Cerrados, 2016.

SAMPAIO, A.C.; SCUDELLER, N; FUMIS, T.F.; ALMEIDA, A.M.DE; PINOTTI, R.N.; GARCIA, M.J.M.; PALLAMIN, M.L. Manejo cultural do maracujazeiroamarelo em ciclo anual visando à convivência com o vírus do endurecimento dos frutos: um estudo de caso. Revista Brasileira de Fruticultura, Jaboticabal, v.30, n. 2, p. 343-347, 2008.
SANGOI, L.; ERNANI, P.R.; LECH, V.A.; RAMPAZZO, C. Volatilização de N-NH3 em decorrência da forma de aplicação de ureia, manejo de resíduos e tipo de solo, em laboratório. Ciência Rural, Santa Maria, v.33, n.4, p.687-692, 2003.

ZACHARIAS, A.O.; JUNQUEIRA, N.T.V.; JUNQUEIRA, K.P.; FALEIRO, F.G., JUNQUEIRA, L.P. Sistemas de condução e podas. In: FALEIRO, F.G; JUNQUEIRA, N.T. V. (ed.). Maracujá: o produtor pergunta, a Embrapa responde. Brasília, DF: Embrapa, 2016. 341 p. (Coleção 500 perguntas, 500 respostas). 